Article

\title{
Synthesis of Biocompatible Hydroxyapatite Using Chitosan Oligosaccharide as a Template
}

\author{
Jinyu Wang ${ }^{1}$, Guanxiong Liu ${ }^{1}$, Jinshuai Chen ${ }^{1}$, Bo Zhao ${ }^{2}$ and Peizhi Zhu ${ }^{1, *}$ \\ Received: 26 October 2015; Accepted: 20 November 2015; Published: 30 November 2015 \\ Academic Editor: Naozumi Teramoto \\ 1 School of Chemistry and Chemical Engineering, Yangzhou University, Yangzhou 225002, China; \\ jinywang2@gmail.com (J.W.); liugangx130@gmail.com (G.L.); chenjsu7@gmail.com (J.C.) \\ 2 Jiangsu Collaborative Innovation Center of Biomedical Functional Materials and Jiangsu Key Laboratory \\ of Biofunctional Materials, School of Chemistry and Materials Science, Nanjing Normal University, \\ Nanjing 210023, China; zhaobo@njnu.edu.cn \\ * Correspondence: pzzhu@yzu.edu.cn; Tel./Fax: +86-514-87975244
}

\begin{abstract}
In this study, a novel biocompatible hydroxyapatite (HA) was synthesized by using chitosan oligosaccharide (COS) as a template. These HA samples were studied by Fourier transform infrared (FTIR) spectroscopy, X-ray diffraction (XRD), X-ray photoelectron spectroscopy (XPS), and transmission electron microscopy (TEM). The biocompatibility of HA samples was evaluated via cell viability, cell morphology and alkaline phosphatase staining of MG-63 cell lines. The results show that HA synthesized in the presence of COS was favorable to proliferation and osteogenic differentiation of MG-63 cells. These hydroxyapatites are potentially attractive biomaterials for bone tissue engineering applications.
\end{abstract}

Keywords: chitosan oligosaccharide; hydroxyapatite; cytotoxicity; MG-63 cell

\section{Introduction}

Over recent years, various biomaterials have been developed for bone tissue engineering applications such as bone graft substitutes, bone repair, biodegradable bone scaffold and bone drug carriers [1-4]. With stricter biocompatibility requirements for materials used in clinic application, biomimetic synthesis of hydroxyapatites with improved biocompatibility is a promising strategy for the clinic application of hydroxyapatites for bone tissue engineering [5-7]. The biomimetic method typically uses a bottom-up approach to design and assemble molecules into a higher order of hierarchy structure [8]. Biomolecules including polysaccharides [6,9,10], collagens [11,12], gelatin $[13,14]$ and peptides [15-17] have attracted extensive attention in regulating HA nucleation and growth during the mineralization process. Wang et al. [11] demonstrated that the nucleation, growth, orientation and structure of bone apatite crystals was predominantly controlled by collagen matrix. Recently, much attention has been focused on the polysaccharide in the bone. Several polysaccharides including maleic chitosan, hyaluronic acid and heparin have been found to play important roles in stabilizing the amorphous calcium phosphate at the early stage of mineralization and regulating the morphology, size and crystallinity of the inorganic apatites $[6,9,10]$. Wise et al. [18] recently suggested that polysaccharides, not proteins, predominantly form an organic-mineral interface. Unlike hydrophobic collagens, the functional groups of polysaccharides can chelate $\mathrm{Ca}^{2+}$ ions and form hydrogen bonds with protonated $\mathrm{PO}_{4}{ }^{3-}$ and $\mathrm{H}_{2} \mathrm{O}$ on the surface of the bone apatites [19].

Chitosan, a linear polysaccharide composed of D-glucosamine and N-acetyl-D-glucosamine, is produced commercially by deacetylation of chitin of crustaceans such as crabs and shrimp. As the degraded products of chitosan by enzymatic and acidic hydrolysis, chitosan oligosaccharides 
(COS) have a lower molecular weight and are readily soluble in aqueous solutions [20]. COS have attracted considerable attention due to their biological activities and biomedical properties including antimicrobial activities, immune-enhancing effects, and anti-tumor activities [21-23].

As a prototype of human bone cells, the osteoblast cell line MG63 have been widely used to evaluate biocompatibility and osteogenic differentiation of materials. The sequential expression of genes for collagen type I and alkaline phosphatase (ALP) is characteristic of osteoblast differentiation of MG-63 cells [24]. In this study, we hypothesize that the amino groups play an important role in regulating the mineralization of apatites, because they have a high affinity for calcium ions in solution. The purpose of this study was to address the effects of the molecular weight and the concentration of COS on the chemical compositions, morphology and biological properties of apatites synthesized by the chemical precipitation method. All products were characterized with Fourier-transform infrared spectroscopy (FTIR), X-ray diffraction (XRD), X-ray photoelectron Spectroscopy (XPS) spectroscopy (XPS), and transmission electron microscopy (TEM). The effects of obtained HA samples on the viability and osteogenic differentiation of MG- 63 cells have been evaluated by MTT assay and alkaline phosphatase staining.

\section{Materials and Methods}

\subsection{Materials}

$\mathrm{Ca}\left(\mathrm{NO}_{3}\right)_{2} \cdot 4 \mathrm{H}_{2} \mathrm{O}$ (AR, Shanghai Chemical Reagent Co., Ltd., Shanghai, China), $\left(\mathrm{NH}_{4}\right)_{2} \mathrm{HPO}_{4}$ (AR, Shanghai Chemical Reagent Co., Ltd., Shanghai, China), $\mathrm{NH}_{3} \cdot \mathrm{H}_{2} \mathrm{O}$ (AR, Shanghai Chemical Reagent Co., Ltd., Shanghai, China), and chitosan oligosaccharide (AR, Linovus Technology, Singapore) were used as received without further purification.

\subsection{Samples Preparation}

In the typical synthesis of $\mathrm{HA}, \mathrm{Ca}\left(\mathrm{NO}_{3}\right)_{2} \cdot 4 \mathrm{H}_{2} \mathrm{O}$ and $\left(\mathrm{NH}_{4}\right)_{2} \mathrm{HPO}_{4}$ were used as the calcium source and phosphorus source, respectively. The different molecular weights of COS were served as soft templates for HA synthesis. All the chemicals were used as received without further purification. The specific synthetic condition of each sample is listed in Table 1. A solution of $\left(\mathrm{NH}_{4}\right)_{2} \mathrm{HPO}_{4}$ and $\mathrm{COS}$ was prepared in deionized water with magnetic stirring, then the mixed solution was heated at $85^{\circ} \mathrm{C}$. Then $\mathrm{Ca}\left(\mathrm{NO}_{3}\right)_{2}$ solution was added dropwisely to the heated solution, meanwhile keeping $\mathrm{pH}$ about 10 by adding ammonium hydroxide solution. After $2 \mathrm{~h}$ stirring, the hydroxyapatite suspension was aged for $24 \mathrm{~h}$. The obtained precipitate was washed by deionized water and ethyl alcohol for three times, and dried with an infrared heat lamp.

Table 1. Synthesizing conditions for preparing apatites with COS as a template.

\begin{tabular}{cccccc}
\hline Sample Name & COS $(\mathbf{g} / \mathbf{L})$ & Molecular Mass of COS & $\mathbf{C a}\left(\mathbf{N O}_{3}\right)_{\mathbf{2}}(\mathbf{m o l} / \mathbf{L})$ & $\left.\left.\mathbf{( N H}_{\mathbf{4}}\right)_{\mathbf{2}} \mathbf{H P O}_{\mathbf{4}} \mathbf{( m o l} / \mathbf{L}\right)$ & $\mathbf{T}\left({ }^{\circ} \mathbf{C}\right)$ \\
\hline CS1000-1 & 10 & 1000 & 0.167 & 0.1 & 85 \\
CS3000- & 10 & 3000 & 0.167 & 0.1 & 85 \\
CS5000-1 & 10 & 5000 & 0.167 & 0.1 & 85 \\
CS1000-2 & 2 & 1000 & 0.167 & 0.1 & 85 \\
CS3000-2 & 2 & 3000 & 0.167 & 0.1 & 85 \\
CS5000-2 & 2 & 5000 & 0.167 & & 85 \\
\hline
\end{tabular}

\subsection{Physical Characterization Methods}

\subsubsection{X-ray Diffraction Measurement}

The crystalline phase of the samples was examined by X-ray diffraction (XRD, D8 ADVANCE, Bruker-AXS, Karlsruhe, Germany) with graphite monochromatized $\mathrm{Cu} \mathrm{K} \alpha$ radiation operating at $40 \mathrm{kV}$ and $40 \mathrm{~mA}$ at room temperature. 


\subsubsection{Fourier Transform Infrared Spectrometry Measurement}

Fourier transform infrared spectrometry (FTIR, ALPHA, BRUKER, Billerica, MA, USA) was used to identify the molecular structure characteristics and, after the sample stage was cleaned up by ethanol wiping, the background was tested from 500 to $3600 \mathrm{~cm}^{-1}$.

\subsubsection{X-ray Photoelectron Spectroscopy}

The elements composition and the atom molar ratio of $\mathrm{Ca}$ to $\mathrm{P}$ of the samples were analyzed by X-ray photo-electronic spectroscopy (XPS, ESCALAB250Xi, ThermoFisher Scientific, Waltham, MA, USA).

\subsubsection{Tecnai F30 Transmission Electron Microscope Measurement}

High resolution transmission electron microscopy (HRTEM, Tecnai C2 F30 S-Twin, FEI, Hillsboro, OR, USA) was carried out to determine particle size and morphology.

\subsection{Cell Viability Test, Cell Morphology and Alkaline Phosphatase Staining Assay}

Human osteosarcoma cell line MG63 cells (American Type Culture Collection, Manassas, VA, USA) were cultured in RPMI 1640 medium (Gibco, Carlsbad, CA, USA) containing 10\% fetal calf serum (Gibco, Carlsbad, CA, USA), $100 \mu \mathrm{g} / \mathrm{mL}$ penicillin and $100 \mu \mathrm{g} / \mathrm{mL}$ streptomycin in a humidified atmosphere with $5 \% \mathrm{CO}_{2}$ at $37^{\circ} \mathrm{C}$. Then MG-63 cells were seeded in a 96-well cell culture plate with a density of $5 \times 10^{3}$ per well. The next day, cells were treated with HA samples at the concentration of $60 \mu \mathrm{g} / \mathrm{mL}$ ( $6 \mu \mathrm{g}$ per well). After 1, 3 and 5 days, the cell viability was evaluated by MTT. Optical microscopy (Olympus BX 51M, Monolith, Japan) was used to observe the morphology of cells.

Alkaline phosphatase staining was performed with nitro blue tetrazolium/5-bromo-4-chloroindolyl-phosphate (BCIP/NBT) Alkaline Phosphatase Color Development Kit (Beyotime Institute of Biotechnology, Nanjing, China) according to manufacturer's instructions. Briefly, MG-63 cells were seeded in a 24-well cell culture plate with a density of $2 \times 10^{4}$ per well. The next day, cells were treated with the HA samples with the concentration of $60 \mu \mathrm{g} / \mathrm{mL}(30 \mu \mathrm{g}$ per well). After co-culture with samples for 4 days, the cells were washed by PBS for three times and fixed by $4 \%$ paraformaldehyde for $20 \mathrm{~min}$. Then the cells were washed with PBS again for three times and incubated with BCIP/NBT staining buffer for $16 \mathrm{~h}$ at room temperature. The stained cells were observed under inverted microscope.

\section{Results and Discussion}

\subsection{Fourier Transform Infrared Spectroscopy}

The FTIR spectra of all as-prepared HA samples are shown in Figure 1. The absorption peak around $566 \mathrm{~cm}^{-1}$ and $603 \mathrm{~cm}^{-1}$ can be assigned as the bending vibration of $\mathrm{PO}_{4}{ }^{3-}[6,7,10]$. The $913 \mathrm{~cm}^{-1}$ peak corresponds to the symmetric stretching vibration of $\mathrm{PO}_{4}{ }^{3-}$. The peaks at $1036 \mathrm{~cm}^{-1}$ and $1122 \mathrm{~cm}^{-1}$ should be assigned to asymmetric stretching vibration of $\mathrm{PO}_{4}{ }^{3-}[6,10]$. The absorption peak around $1385 \mathrm{~cm}^{-1}$ belongs to $\mathrm{CO}_{3}{ }^{2-}$ asymmetric stretching vibration, which indicated that there is a partial substitution of $\mathrm{CO}^{2-}$ for $\mathrm{PO}_{4}{ }^{3-}$ (B-type) [7]. The substitution of carbonate for both $\mathrm{PO}_{4}{ }^{3-}$ in HA was affected by the different concentration and molecular weight of COS. 


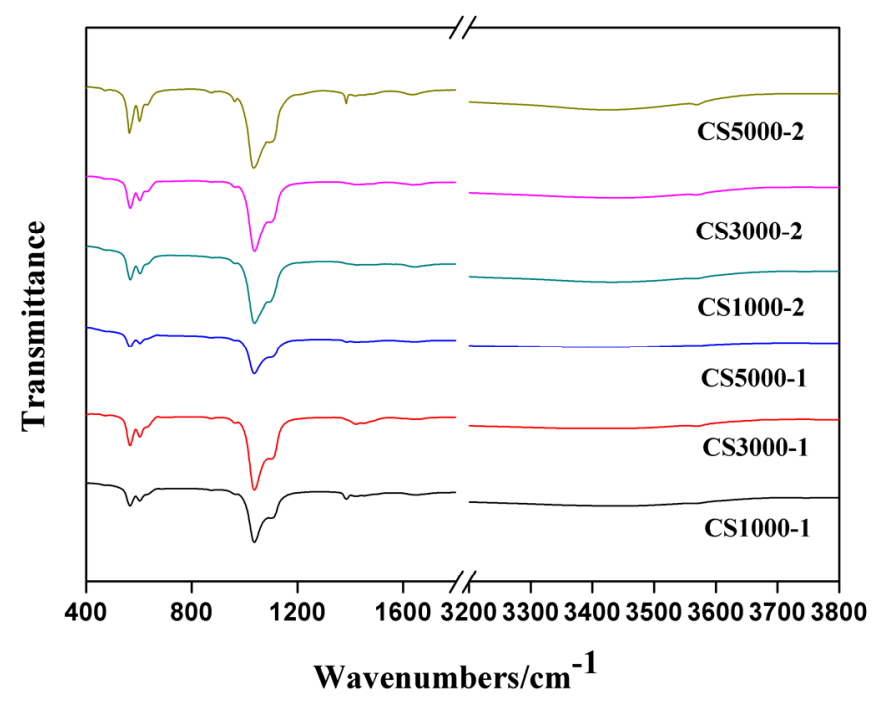

Figure 1. FTIR spectra of HA samples synthesized under different conditions.

\subsection{X-Ray Photoelectron Spectroscopy}

XPS characterization (Figure 2) was used to analyze the $\mathrm{Ca} / \mathrm{P}$ ratio of synthesized apatite samples [25-27]. As shown in Table 2, the ratio between calcium and phosphate is still less than 1.67 in theory, which may be caused by the calcium deficiency on the surface of the HA lattice [13]. The ratio between calcium and phosphate of synthetic samples has no significant differences in a reasonable range. Finally, the characteristic peaks of the $\mathrm{N}$ element in the XPS analysis cannot be seen, which indicates that COS had been washed cleanly.

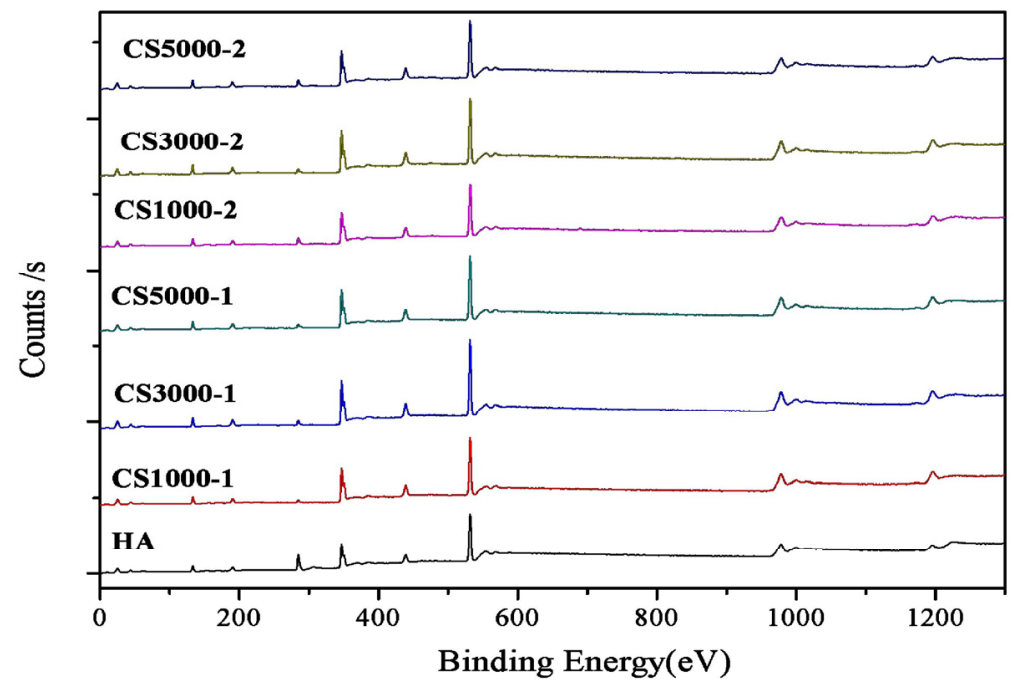

Figure 2. XPS spectra of as-synthesized HA samples under different conditions.

Table 2. Quantities and molar ratios of synthesized HA samples.

\begin{tabular}{ccccccc}
\hline wt \% & CS1000-1 & CS3000-1 & CS5000-1 & CS1000-2 & CS3000-2 & CS5000-2 \\
\hline Ca (atomic \%) & 18.25 & 18.04 & 17.59 & 16.45 & 18.43 & 16.76 \\
P (atomic \%) & 12.60 & 12.59 & 11.93 & 11.63 & 12.59 & 11.57 \\
Ca/P ratio & 1.45 & 1.43 & 1.47 & 1.41 & 1.46 & 1.45 \\
\hline
\end{tabular}




\subsection{X-Ray Diffraction Studies}

XRD patterns of the six synthesized HA samples are shown in Figure 3. The diffraction peaks of all HA samples agree with those of pure $\mathrm{HA}$ at $2 \theta$ values of $25.9^{\circ}, 31.7^{\circ}, 32.9^{\circ}, 39.8^{\circ}, 46.7^{\circ}, 49.5^{\circ}$ and $53.1^{\circ}$, which are indexed to (002), (211), (300), (310), (222), (213) and (004) planes, respectively $[6,7,10]$. The intense bands at around $2 \theta=26^{\circ}$ and $2 \theta=33^{\circ}$ prove that the samples are predominantly HA. The patterns of HA samples with broader bands are similar to those minerals in human bones [28]. The amino groups on the surface of $\operatorname{COS}$ can chelate $\mathrm{Ca}^{2+}$ ions to form ionic clusters for the nucleation of minerals and function like a natural template for the apatite crystal to grow.

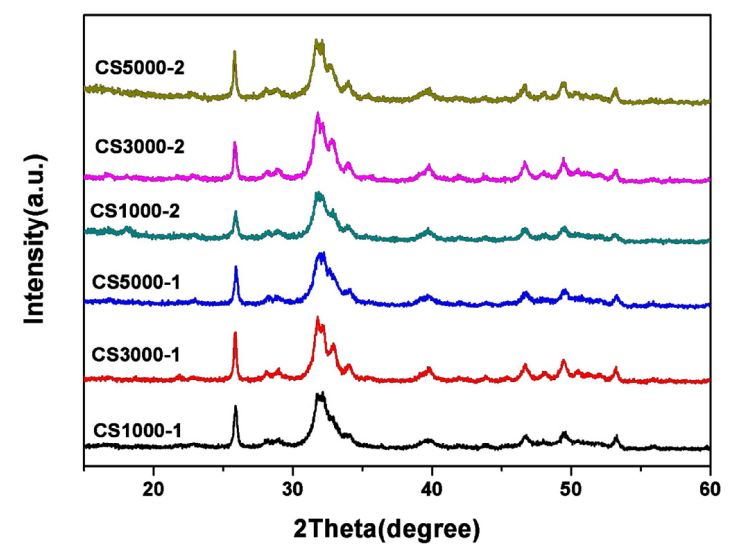

Figure 3. XRD patterns of as-prepared HA samples under different conditions.

\subsection{Morphology Analysis Using TEM}

Figure 4 shows TEM micrographs of the as-synthesized samples. The HA samples COS1000-1 and COS 1000-2 synthesized by using COS of 1000 molecular weight (MW) as a template featured very irregular needle-like morphology (Figure 4a,e). The crystal structure of the HA samples COS3000-1 and COS 3000-2 synthesized with 3000 molecular weight (MW) COS is close to the irregular nanorods (Figure $4 \mathrm{~b}, \mathrm{f}$ ). With the increase of the COS concentration, the morphology and size of apatites crystals show few changes. However, as the molecular weight of COS increase, the size of the HA crystals also visibly increase. This indicates that the presence of COS in solution may interfere with the growth of HA crystals. Longer chains of larger COS molecules chelate with calcium ions on the surface of apatite crystals, function as templates to attract calcium ions to promote nucleation of minerals and guide the growth of crystals along the chains.

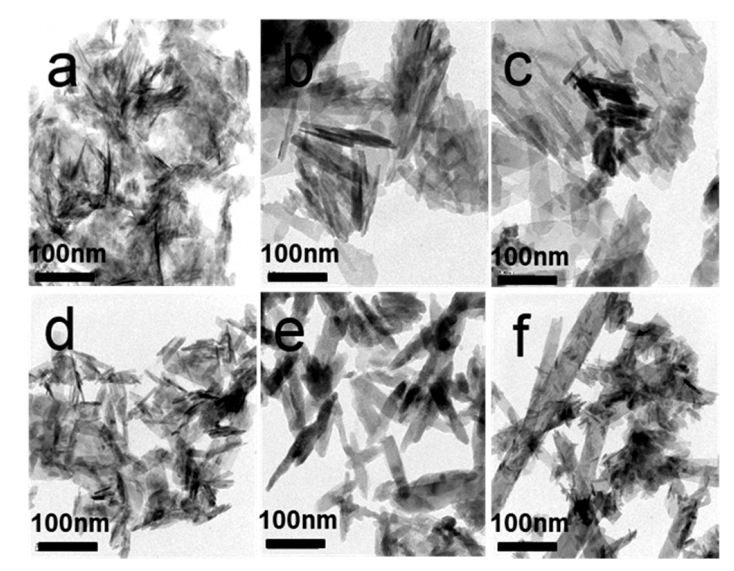

Figure 4. TEM micrographs of HA samples: (a) CS1000-1; (b) CS3000-1; (c) CS5000-1; (d) CS1000-2; (e) CS3000-2; (f) CS5000-2. 


\subsection{Cell Viability Test, Cell Morphology and Alkaline Phosphatase Staining Assay}

The in vitro biocompatibility of HA samples was assessed by MTT assay on an MG-63 cell line. The MG-63 cells were co-cultured with HA samples for 1 day, 3 days and 5 days. As shown in Figure 5, after 1 day culturing, the cell viability after culturing with HA samples were slightly lower than control group, which could be explained by the cytotoxicity of HA nanoparticles. Although HA has been widely used as biomaterials for tissue engineering and drug carriers, it has been reported that hydroxyapatite nanoparticles induce apoptosis on MC3T3-E1 cells and tissue cells in SD rats [29]. The cytotoxicity of HA nanoparticles is mostly dependent on its shape and cell types [30]. After 1 day culturing, the cell viability of COS3000-1 was slightly higher than other group, indicating that the molecular weight and concentration might have an impact on biocompatibility of HA samples. From Figure 5, it can be seen that the viability of MG-63 cells incubated with each sample $(60 \mathrm{ug} / \mathrm{mL})$ for 5 days still displays few differences between each other, except that COS3000-1 shows a bit better vitality. The cell morphology of MG-63 cells co-cultured with COS3000-1 was shown in Figure 6. The Figure 6a shows the cell morphology images observed from MG-63 cells cultured with HA samples at $60 \mu \mathrm{g} / \mathrm{mL}$ concentration for 1 day. The MG63 looked natural, attached and well-spread on the dish surface. Figure $6 \mathrm{~b}$ shows that MG-63 cells became extremely dense after $72 \mathrm{~h}$ co-culturing with $60 \mathrm{ug} / \mathrm{mL}$ of COS3000-1.

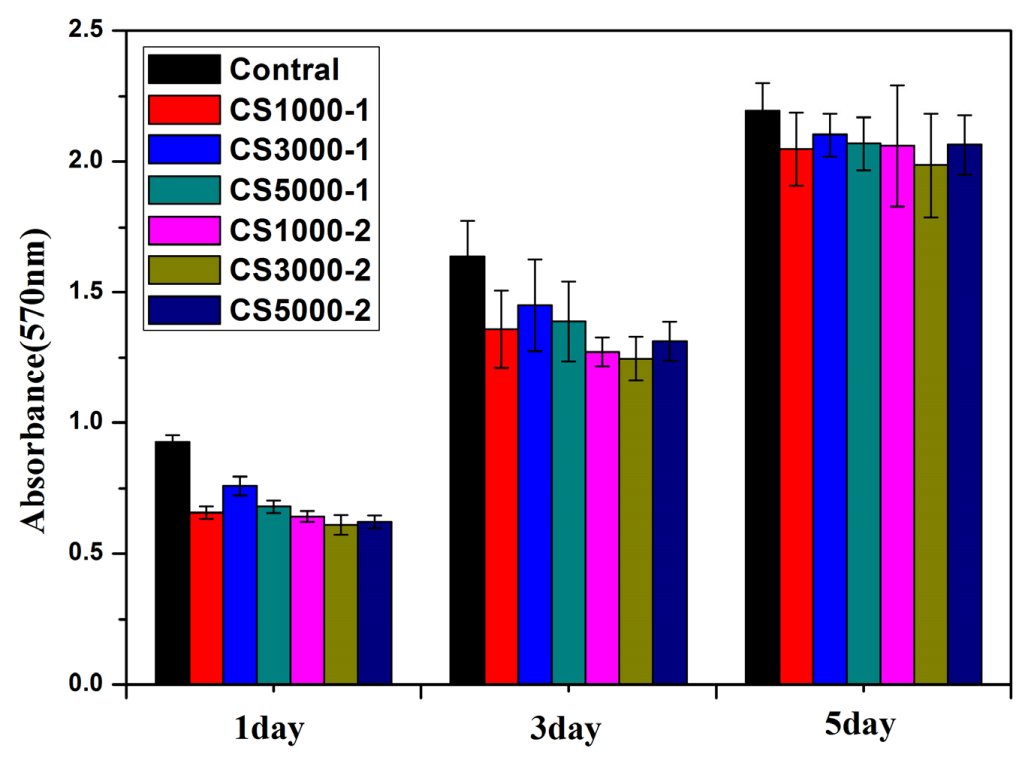

Figure 5. In vitro cytotoxicity of MG-63 cell lines after culturing with HA samples.
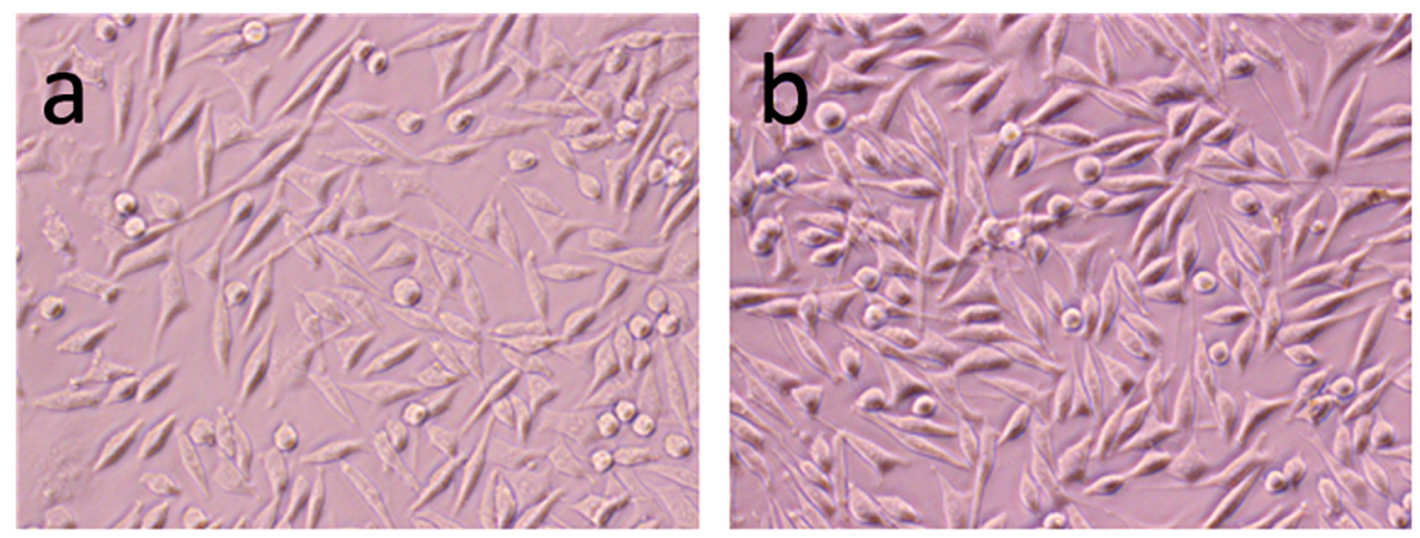

Figure 6. Cell topography of MG-63 cells co-cultured with $60 \mathrm{ug} / \mathrm{mL}$ of COS3000-1 sample for different times: (a) $24 \mathrm{~h}$; (b) $72 \mathrm{~h}$. 
The distinct $570 \mathrm{~nm}$ absorbance for MTT could be ascribed to the difference in the morphology, carbonate content and the $\mathrm{Ca} / \mathrm{P}$ ratio of the synthesized HA crystals. The substitution of carbonate of HA can enhance its solubility, which makes HA biologically active [6,10]. In addition, calcium-deficient apatites are also of biological importance since the catalytic activity of HA is proportional to the calcium deficiency of the sample. Large amounts of carbon, non-stoichiometric $\mathrm{Ca} / \mathrm{P}$ ratio and appropriate nano-morphology may be the co-contributors to the biocompatibility of apatites [31,32]. After 3 days incubation, all HA samples only show lower absorbance than the control group, but little difference between each other. Similar results are obtained after 5 days incubation. This can be explained by little structural difference between each sample characterized by FTIR, XPS and TEM. However, COS3000-1 displays a bit better vitality, which is mainly due to its appropriate morphology of crystalline, low $\mathrm{Ca} / \mathrm{P}$ ratio as well as certain amounts of carbonate substitution. The cell vitality test shows that these HA samples are biological apatites and biocompatible with the human osteosarcoma MG-63 cell line.

Alkaline phosphatase expression is indicative of osteogenesis. As shown in Figure 7, after co-culturing with $60 \mu \mathrm{g} / \mathrm{mL}$ concentration of HA samples for 4 days, alkaline phosphatase is expressed in large amounts in the cell cytosol of MG-63 cells. Since alkaline phosphate is expressed in large amounts in the differentiation phase of pre-osteoblastic MG63 cells, the assay is able to show early osteoblastic phenotypic expressions, which is indicative of osteogenesis [33]. The results indicate that all synthesized HA samples prepared with different molecular weights and concentrations of COS have similar impacts on the growth and osteogenic differentiation MG-63 cells. The ALP assay results demonstrate that the HA samples synthesized with a higher concentration of $\operatorname{COS}$ (Figure $6 \mathrm{a}-\mathrm{c}$ ) show better osteogenic differentiation activity.
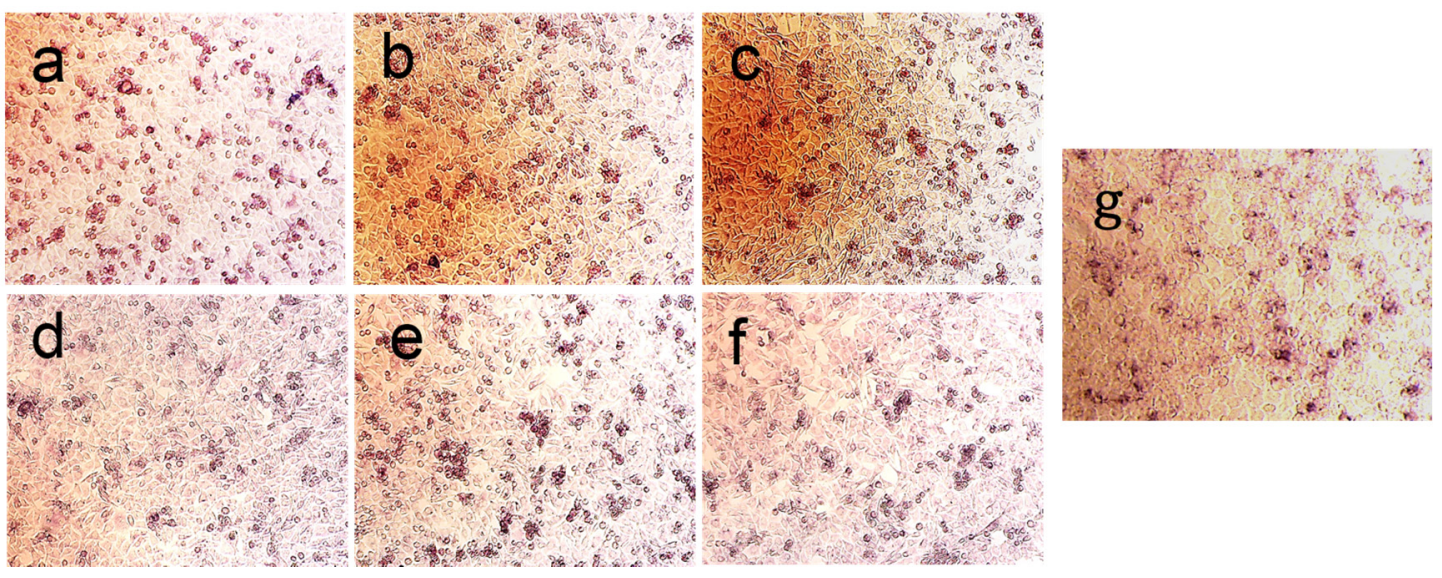

Figure 7. ALP activity images of MG-63 cells co-cultured with HA samples: (a) CS1000-1; (b) CS3000-1; (c) CS5000-1; (d) CS1000-2; (e) CS3000-2; (f) CS5000-2; (g) Control.

\section{Conclusions}

In this study, chitosan oligosaccharides with different molecular weights were used as the templates to synthesize apatite samples. The effects of the chitosan oligosaccharide concentration and the molecular weight on the chemical composition, morphology, and biocompatibility of as-synthesized apatites were investigated using FTIR, XRD and TEM characterization techniques. It was found that these non-stoichiometric carbonated apatites were favorable to the proliferation and differentiation of MG-63 cells. These novel biocompatible hydroxyapatites synthesized by using chitosan oligosaccharide as a template are promising candidates for bone tissue engineering applications. 
Acknowledgments: This work was supported by Jiangsu Province for specially appointed professorship to Peizhi Zhu, research funds from Yangzhou University, research funds from Liuda Rencai Gaofeng, the Technology Support Program of Science and Technology Department of Jiangsu Province (BE2015703), the Jiangsu agricultural science and Technology Innovation Fund Project (CX(14)2127), the support from the Testing Center of Yangzhou University, and A Project Funded by the Priority Academic Program Development of Jiangsu Higher Education Institutions.

Author Contributions: Peizhi Zhu proposed the topic of this study and designed the experiments. Jinyu Wang, Guanxiong Liu and Jinshuai Chen performed the synthesis, characterization, and analysis of materials and drafted the manuscript. Zhao Bo performed and analyzed the cytotoxicity assays and drafted the manuscript. Peizhi Zhu and Jinyu Wang analyzed the data and wrote the final manuscript. All authors read and approved the final manuscript.

Conflicts of Interest: The authors declare no conflict of interest.

\section{References}

1. Bohner, M. Resorbable biomaterials as bone graft substitutes. Mater. Today 2010, 13, 24-30. [CrossRef]

2. Iwasashi, M.; Funayama, T.; Watanabe, A.; Noguchi, H.; Tsukanishi, T.; Suetsugu, Y.; Makihara, T.; Ochiai, N.; Yamazaki, M.; Sakane, M. Bone regeneration and remodeling within a unidirectional porous hydroxyapatite bone substitute at a cortical bone defect site: Histological analysis at one and two years after implantation. Materials 2015, 8, 4884-4894. [CrossRef]

3. Yazdimamaghani, M.; Razavi, M.; Vashaee, D.; Tayebi, L. Surface modification of biodegradable porous Mg bone scaffold using polycaprolactone/bioactive glass composite. Mater. Sci. Eng. C 2015, 49, 436-444. [CrossRef] [PubMed]

4. Qiu, Z.Y.; Cui, Y.; Tao, C.S.; Zhang, Z.Q.; Tang, P.F.; Mao, K.Y.; Wang, X.M.; Cui, F.Z. Mineralized collagen: Rationale, current status, and clinical applications. Materials 2015, 8, 4733-4750. [CrossRef]

5. Gentile, P.; Wilcock, C.J.; Miller, C.A.; Moorehead, R.; Hatton, P.V. Process optimisation to control the physico-chemical characteristics of biomimetic nanoscale hydroxyapatites prepared using wet chemical precipitation. Materials 2015, 8, 2297-2310. [CrossRef]

6. Deng, Y.; Sun, Y.H.; Chen, X.F.; Zhu, P.Z.; Wei, S.C. Biomimetic synthesis and biocompatibility evaluation of carbonated apatites template-mediated by heparin. Mater. Sci. Eng. C 2013, 33, 2905-2913. [CrossRef] [PubMed]

7. Kong, L.; Gao, Y.; Cao, W.; Gong, Y.; Zhao, N.; Zhang, X. Preparation and characterization of nano-hydroxyapatite/chitosan composite scaffolds. J. Biomed. Mater. Res. A 2005, 75, 275-282. [CrossRef] [PubMed]

8. Kunz, W.; Kellermeier, M. Beyond biomineralization. Science 2009, 323, 344-345. [CrossRef] [PubMed]

9. Zhong, C.; Chu, C.C. Biomimetic mineralization of acid polysaccharide-based hydrogels: Towards porous 3-dimensional bone-like biocomposites. J. Mater. Chem. 2012, 22, 6080-6087. [CrossRef]

10. Li, Q.H.; Li, M.; Zhu, P.Z.; Wei, S.C. In vitro synthesis of bioactive hydroxyapatite using sodium hyaluronate as a template. J. Mater. Chem. 2012, 22, 20257-20265. [CrossRef]

11. Wang, Y.; Azaïs, T.; Robin, M.; Vallée, A.; Catania, C.; Legriel, P.; Pehau-Arnaudet, G.; Babonneau, F.; Giraud-Guille, M.M.; Nassif, N. The predominant role of collagen in the nucleation, growth, structure and orientation of bone apatite. Nat. Mater. 2012, 11, 724-733. [CrossRef] [PubMed]

12. Roveri, N.; Falini, G.; Sidoti, M.C.; Tampieri, A.; Landi, E.; Sandri, M.; Parma, B. Biologically inspired growth of hydroxyapatite nanocrystals inside self-assembled collagen fibers. Mater. Sci. Eng. C 2003, 23, 441-446. [CrossRef]

13. Rosseeva, E.V.; Buder, J.; Simon, P.; Schwarz, U.; Frank-Kamenetskaya, O.V.; Kniep, R. Synthesis, characterization, and morphogenesis of carbonated fluorapatite-gelatine nanocomposites: A complex biomimetic approach toward the mineralization of hard tissues. Chem. Mater. 2008, 20, 6003-6013. [CrossRef]

14. Liu, X.; Smith, L.A.; Hu, J.; Ma, P.X. Biomimetic nanofibrous gelatin/apatite composite scaffolds for bone tissue engineering. Biomaterials 2009, 30, 2252-2258. [CrossRef] [PubMed]

15. Gungormus, M.; Branco, M.; Fong, H.; Schneider, J.P.; Tamerler, C.; Sarikaya, M. Self assembled bi-functional peptide hydrogels with biomineralization-directing peptides. Biomaterials 2010, 31, 7266-7274. [CrossRef] [PubMed] 
16. Hartgerink, J.D.; Beniash, E.; Stupp, S.I. Self-Assembly and Mineralization of peptide-amphiphile nanofibers. Science 2001, 294, 1684-1688. [CrossRef] [PubMed]

17. Mata, A.; Geng, Y.; Henrikson, K.J.; Aparicio, C.; Stock, S.R.; Satcher, R.L.; Stupp, S.I. Bone regeneration mediated by biomimetic mineralization of a nanofiber matrix. Biomaterials 2010, 31, 6004-6012. [CrossRef] [PubMed]

18. Wise, E.R.; Maltsev, S.; Davies, M.E.; Duer, M.J.; Jaeger, C.; Loveridge, N.; Murray, R.C.; Reid, D.G. The organic-mineral interface in bone is predominantly polysaccharide. Chem. Mater. 2007, 19, 5055-5057. [CrossRef]

19. Zhu, P.Z.; Xu, J.D.; Sahar, N.; Morris, M.D.; Kohn, D.H.; Ramamoorthy, A. Time-resolved dehydration-induced structural changes in an intact bovine cortical bone revealed by solid-state NMR spectroscopy. J. Am. Chem. Soc. 2009, 131, 17064-17065. [CrossRef] [PubMed]

20. Zou, P.; Yang, X.; Wang, J. Advances in characterisation and biological activities of chitosan and chitosan oligosaccharides. Food Chem. 2015, 190, 1174-1181. [CrossRef] [PubMed]

21. Choi, B.K.; Kim, K.Y.; Yoo, Y.J.; Oh, S.J.; Choi, J.H.; Kim, C.Y. In vitro antimicrobial activity of a chitooligosaccharide mixture against Actinobacillus actinomycetemcomitans and Streptococcus mutans. Int. J. Antimicrob. Agents 2001, 18, 553-557. [CrossRef]

22. Feng, J.; Zhao, L.; Yu, Q. Receptor-mediated stimulatory effect of oligochitosan in macrophages. Biochem. Biophys. Res. Commun. 2004, 317, 414-420. [CrossRef] [PubMed]

23. Salah, R.; Michaud, P.; Mati, F.; Harrat, Z.; Lounici, H.; Abdi, N.; Drouiche, N.; Mameri, N. Anticancer activity of chemically prepared shrimp low molecular weight chitin evaluation with the human monocyte leukaemia cell line, THP-1. Int. J. Biol. Macromol. 2013, 52, 333-339. [CrossRef] [PubMed]

24. Yoshida, T.; Kikuchi, M.; Koyama, Y.; Takakuda, K. Osteogenic activity of MG63 cells on bone-like hydroxyapatite/collagen nanocomposite sponges. J. Mater. Sci. 2010, 21, 1263-1272.

25. Kalita, S.J.; Verma, S. Nanocrystalline hydroxyapatite bioceramic using microwave radiation: Synthesis and characterization. Mater. Sci. Eng. C 2010, 30, 295-303. [CrossRef]

26. He, Q.J.; Huang, Z.L.; Liu, Y.; Chen, W.; Xu, T. Template-directed one-step synthesis of flowerlike porous carbonated hydroxyapatite spheres. Mater. Lett. 2007, 61, 141-143. [CrossRef]

27. Lu, H.B.; Campbell, C.T.; Graham, D.J.; Ratner, B.D. Surface characterization of hydroxyapatite and related calcium phosphates by XPS and TOF-SIMS. Anal. Chem. 2000, 72, 2886-2894. [CrossRef] [PubMed]

28. Meneghini, C.; Dalconi, M.C.; Nuzzo, S.; Mobilio, S.; Wenk, R.H. Rietveld refinement on X-ray diffraction patterns of bioapatite in human fetal bones. Biophys. J. 2003, 84, 2021-2029. [CrossRef]

29. Wang, L.; Zhou, G.; Liu, H.; Niu, X.; Han, J.; Zheng, L.; Fan, Y. Nano-hydroxyapatite particles induce apoptosis on MC3T3-E1 cells and tissue cells in SD rats. Nanoscale 2012, 4, 2894-2899. [CrossRef] [PubMed]

30. Zhao, X.; Ng, S.; Heng, B.C.; Guo, J.; Ma, L.; Tan, T.T.Y.; Ng, K.W.; Loo, S.C.J. Cytotoxicity of hydroxyapatite nanoparticles is shape and cell dependent. Arch. Toxicol. 2013, 87, 1037-1052. [CrossRef] [PubMed]

31. Dorozhkin, S.V. Calcium orthophosphates. J. Mater. Sci. 2007, 42, 1061-1095. [CrossRef]

32. Narasaraju, T.; Phebe, D. Some physico-chemical aspects of hydroxylapatite. J. Mater. Sci. 1996, 31, 1-21. [CrossRef]

33. Hattar, S.; Berdal, A.; Asselin, A.; Loty, S.; Greenspan, D.; Sautier, J. In vitro interactions of glasses with osteoblast-like cells. Eur. Cell Mater. 2002, 4, 61-69. [PubMed]

(C) 2015 by the authors; licensee MDPI, Basel, Switzerland. This article is an open access article distributed under the terms and conditions of the Creative Commons by Attribution (CC-BY) license (http://creativecommons.org/licenses/by/4.0/). 